\title{
The Effect of Collaborative Learning on Academic Motivation
}

\begin{abstract}
This paper explores the effect of collaborative learning on academic motivation among students from 17 institutions throughout the United States. Even in the presence of a wide array of potential confounders, collaborative learning exerted a statistically significant and positive influence on students' academic motivation levels across four years of undergraduate education. Tests for the presence of interaction effects suggest that the relationship between collaborative learning and academic motivation is similar for all students, regardless of racial or ethnic background.
\end{abstract}

\section{KEYWORDS}

collaborative learning, cooperative learning, academic motivation, college students

\section{INTRODUCTION}

A substantial body of evidence links collaborative learning activities to a variety of important college student outcomes (for an extensive review of this evidence, see Barkley, Cross, and Major 2014). Parallel to these scholarly inquiries, academic motivation continues to be a heavily studied topic in education (Grouzet, Otis, and Pelletier 2006; Stover et al. 2012). Despite this research, few studies explicitly investigate potential linkages between collaborative learning and changes in students' academic motivation. This gap in the literature is somewhat surprising given the heightened focus among instructors on incorporating active and collaborative learning strategies into university classrooms (Freeman et al. 2014) as well as the substantial number of studies examining student motivation levels in higher education, generally, and specifically among certain student subpopulations such as millennials (e.g., Crone and MacKay 2007; Komarraju, Musulkin, and Bhattacharya 2010). Next, aside from some studies that explore the influence of active learning strategies on group members' motivation to learn (Ames and Ames 1984; Benware and Deci 1984; Jones et al. 2013) there is a dearth of contemporary research that examines this issue by following students from multiple institutions over an extended period of time. As Järvelä, Volet, and Järvenoja (2010) note, researchers have much to learn with respect to how social contexts influence motivation within educational settings (see also Reynolds and Weigand 2010).

The current investigation addresses this lacuna in the literature by using a longitudinal pretestposttest design to determine whether exposure to collaborative learning has a net positive effect on academic motivation over four years of university. Next, researchers studying this topic often limit their analyses to specific academic majors and single institutions (e.g., Benware and Deci 1984; Jones et al. 2013), thus raising concerns about potential generalizability issues. To address this issue, the current investigation uses data from multiple institutions throughout the U.S. Lastly, evidence suggests that 
compared to their White counterparts, collaborative learning may confer certain benefits to racial and ethnic minority students (e.g., Barkley, Cross, and Major 2014; Slavin and Oickle 1981; Springer, Stanne, and Donovan 1999; Treisman 1985). Researchers hypothesize this may occur as a result of students placing greater importance upon the use of peer groups in educational settings as well as enhanced within-group cooperation among racial and ethnic minority students (Slavin and Oickle 1981). As such, this study also considers whether race moderates the relationship between collaborative learning and academic motivation.

\section{LITERATURE REVIEW}

\section{Collaborative learning}

"Collaborative learning" is generally used as an umbrella term to describe an activity whereby students work together to achieve a shared learning goal (Barkley, Cross, and Major 2014). This method differs from the dominant form of instruction of lecture/notetaking used in higher education settings (McKeachie, Svinicki, and Hofer 2006; Raver and Maydosz 2010) in that it requires students to take a more active role in their own learning versus passively receiving information from an instructor. Collaborative learning — which is generally considered a more effective educational approach than passive forms of learning (Johnson, Johnson, and Smith 2007; Terenzini et al. 2001; ) -is viewed by scholars as an especially promising pedagogical approach in higher education instruction (Tinto 1997, 1998). As Astin (1993) argues, having students work collaboratively on an academic task, "may be more potent than traditional methods of pedagogy because it motivates students to become more active and more involved participants in the learning process" (427).

Unsurprisingly, a substantial body of literature connects the use of collaborative learning activities to a range of important student outcomes. For example, collaborative learning appears to increase one's odds of persisting to the second year of university directly (Tinto 1999), as well as indirectly through the enhancement of one's interactions with peers (Loes et al. 2017). Students' use of collaborative learning is also positively associated with academic achievement (Springer, Stanne, and Donovan 1999), need for cognition (Castle 2014), and critical thinking (Loes and Pascarella 2017). Scholars link collaborative learning strategies with enhanced attitudes toward instructors and self-esteem (Laal and Ghodsi 2012), social interdependence and peer support (Johnson, Johnson, and Smith 1991), as well as higher levels of openness to diversity via greater frequency of interactions with diverse others (Loes, Culver, and Trolian 2018).

\section{Academic motivation}

Broadly, motivation refers to an influence that stimulates one's desire to complete a task or achieve a goal (Schunk and Zimmerman 2012). Applied to educational contexts, Vallerand and Blssonnette (1992) identify different types of motivation orientations: intrinsic, extrinsic, and amotivation. An intrinsic motivation reflects a degree of self-determination driven by a desire to enhance personal satisfaction that may or may not confer benefits to the individual, whereas extrinsic motivation is a behavior driven by external rewards. In contrast, amotivation reflects an absence of either intrinsic or extrinsic motivation (Legault, Green-Demers, and Pelletier 2006).

Academic motivation is commonly understood through both intrinsic and extrinsic conceptualizations of motivation. As Brophy (2004) notes, academic motivation differs from extrinsic and intrinsic motivation, but it may coexist with either of these concepts—-"students may be motivated 
to learn from a lesson or activity whether or not they find its content interesting or its processes enjoyable" (16). In educational settings, intrinsic motivation generally refers to an individual's internal proclivity to apply effort in attaining academic goals. More specifically, this conceptualization of motivation reflects the inherent satisfaction one perceives they will derive from a particular academic pursuit (Hulleman et al. 2016; Wu 2019), as well as one's drive to achieve an educational goal, especially within social settings (Ambrose et al. 2010). Frequently, then, educational research often examines academic motivation as a manifestation of a student's intrinsic drive to learn (Eccles and Wigfield 2002). Extrinsic motivation, in contrast, tends to be external to the student and may manifest in ways such as a student desiring to complete an academic task or goal as a result of wanting to please one's parents or to earn more money, for example (Twenge and Donnelly 2016).

Similar to other dimensions of student development, academic motivation is malleable and appears to change throughout a student's time in university (Brouse et al. 2010; Kowalski 2007; Ratelle et al. 2004) generally decreasing throughout the university years (Blaich and Wise 2011; Brouse et al. 2010). Related, scholars connect academic motivation to a range of important higher education student outcomes such as academic engagement (Wu 2019), persistence (Allen 1999), cognitive engagement (Walker, Greene, and Mansell 2006), increased retention of material and depth of learning (Benware and Deci 1984; Seli et al. 2016), and grades (Struthers, Perry, and Menec 2000; Wu 2019), for example.

In addition to the robust body of literature connecting academic motivation to a range of important student outcomes, several studies also examine academic motivation as an outcome measure, including investigations that examine the potential connection between students' social interactions and their subsequent motivation. Researchers emphasize the influence of social environments, generally, on individuals' motivation levels and goals (Ambrose et al. 2010). Namely, they assert that certain educational activities, such as collaborative learning, provide a context through which students can hold one another accountable, at least to some extent, in achieving shared learning goals (Laal, Geranpaye, and Dunkin 2013).

Accordingly, investigations at the secondary (Goodenow and Grady 1993) and tertiary (Eyler 2018; Panitz 1999) levels of education suggest students' academic motivation is influenced through one especially important dimension of one's educational experience-interaction with one's peers. Despite the limited work noted earlier (Ames and Ames 1984; Benware and Deci 1984; Jones et al. 2013), however, there is less recent research regarding how collaborative learning activities may influence the academic motivation of university students. Some contemporary work provides a persuasive rationale for how learning occurs in social settings. For example, Eyler (2018) argues that partly through the work of social psychologists, researchers' advances in pedagogy are often based on the evidence illustrating a shift away from focusing on specific instructor practices, and instead toward a greater focus on how social dynamics influence student outcomes. More specifically, researchers argue that one's social bonds - such as those often cultivated in collaborative learning settings — are antecedents to indicators of student success, such as openness to difference, grades, and persistence (Eyler 2018; Loes et al. 2017).

It is also important to note that some evidence suggests collaborative learning does not affect all students similarly. In particular, collaborative learning appears to provide some unique benefits to racial and ethnic minority students (Barkley, Cross, and Major 2014). For example, scholars link exposure to collaborative learning to higher rates of university persistence for Black (versus non-Black) students (Treisman 1985), as well as enhanced academic achievement among Black and Hispanic engineering students (Springer, Stanne, and Donovan 1999). Similar evidence is also reported by Slavin and Oickle 
(1981) in their study on elementary students suggesting Black students benefit more in terms of achievement than their White counterparts as a result of learning collaboratively. Despite this evidence, however, no collegiate research to date explores whether race moderates the relationship between collaborative learning and academic motivation.

\section{THEORETICAL FRAMEWORK}

Typically situated within the constructivist literature, collaborative learning is grounded in the early works of Jean Piaget and Lev Vygotsky. Although not central to his theory of learning, Piaget $(1926,1950)$ acknowledged the potential of the learning environment on student development. In particular, he argued that when students are in a setting that allows them to interact with one another in the learning process, the exposure to the intellectual diversity of others enhances their learning. This exposure, then, provides students with an opportunity to reexamine their beliefs and perspectives in the context of the views of other group members. Piaget argued that the work students complete cooperatively leads to cognitive conflict which in turn stimulates their cognitive growth.

Accordingly, researchers assert that students' social experiences exert a positive influence on their motivation and academic achievement (see Wentzel 1999, for example). Related, Vygotsky (1978) argued that an individual's development is best understood within the context of their social milieu (Deci and Ryan 2012; Tudge and Rogoff 1989). More specifically, he argued that students co-construct knowledge and thus transform "the interpersonal activity into an intrapersonal one" (Stump et al. 2011, 477). As such, and typically positioned within the work of Vygotsky's zone of proximal development, scholars hypothesize that students' motivation is enhanced when they take a more active role in their own learning (e.g., Cicuto and Torres 2016).

Based on the theoretical frameworks advanced by El'konin (1972) and Vygotsky (1978) who focus on the influence of the environmental and situational influences affecting learning, Sivan (1986) uses social constructivist theory to explain the influence of working collaboratively on changes in students' motivation. Specifically, she argues that the individual student is not the sole agent of changes in one's level of motivation. Rather, motivation is best understood as a socially negotiated process. Accordingly, more active forms of instruction — such as collaborative learning-provide contexts in which peers can enhance group members' motivation to learn through formal and informal mechanisms of accountability (Tolsgaard, Kulasegaram, and Ringsted 2016). As Järvelä, Volet, and Järvenoja (2010) point out, group members help to enforce or encourage individual motivation to achieve the overall group's goals. Collectively, this work provides a persuasive rationale for why students' interactions with others in an educational setting may exert a positive influence on their academic motivation.

Given the research and theory presented here, I offer the following hypotheses: First, even in the presence of a wide range of potential confounding influences, including a parallel pretest measure of the outcome, exposure to collaborative learning will have a statistically significant, positive net influence on end-of-fourth year academic motivation. Next, race will moderate the influence of collaborative learning on academic motivation. Specifically, based on the evidence noted above, racial and ethnic minority students who engage in collaborative learning will have greater gains in academic motivation compared to their White counterparts. 


\section{RESEARCH METHODS}

\section{Samples}

\section{Institutional sample}

This study used data from the Wabash National Study on Liberal Arts Education (WNS). The WNS was a longitudinal investigation funded by the Center of Inquiry in the Liberal Arts at Wabash College. The phrases "liberal arts college" and "university" are commonly used interchangeably, as these institutions both grant a four-year undergraduate degree. Although the notion of the "liberal arts" (i.e., education that focuses on broad ideas in an effort to develop well-rounded graduates, in contrast to a more technical or vocational curricular focus) exists in Europe (van der Wende 2011), liberal arts colleges reflect a somewhat distinct American idea. Although universities are very similar to liberal arts colleges in the U.S., the latter historically focus on the arts and sciences and undergraduate education, house many of their students on-campus, and intentionally encourage the development of close faculty/student academic relationships (Baker, Baldwin, and Makker 2012).

Given the focus of the influence of a liberal arts education on student outcomes, liberal arts schools were purposefully oversampled from the 60 higher education institutions that responded to the national invitation to participate in the study. The phrase "liberal arts" used here refers specifically to institutions that meet the Carnegie classification of "baccalaureate arts \& sciences" "Carnegie Classifications: Undergraduate Instructional Program Classification” n.d.). The institutional sample consists of 17 schools in 11 states from four general regions in the U.S.: Midwest, West, Southeast, and Northeast. The 17 institutions consist of 11 liberal arts colleges and six universities. These schools are very diverse in terms of size, location, and academic selectivity.

\section{Student sample}

Respondents consisted of full-time undergraduate students at the 17 institutions in the sample. At larger institutions, investigators selected participants randomly from the incoming class (except for the largest school in the sample where they obtained the participants randomly from the entire incoming student body in the College of Arts and Sciences). For the smaller institutions in the study, however, the sample consisted of the entire incoming first-year class. Investigators provided a cash incentive to each respondent during both data collection periods, and they advised all participants that the information they provided to the researchers would remain completely confidential.

\section{Data collection}

\section{Initial data collection}

The first wave of the data collection occurred in the beginning of the fall 2006 term.

Investigators collected data from a total of 4,193 students in this phase of the data collection period. This portion of the data collection consisted of ascertaining student background information such as demographic characteristics and aspects of their family life before university. This stage also included having respondents complete a battery of instruments to gauge their intellectual and personal development.

\section{Follow-up data collection}

The second wave of the data collection occurred in the spring 2010 term. Students completed the National Survey of Student Engagement (NSSE) ("Survey Instruments" n.d.) instrument as well as the 
Wabash Student Experiences Survey (Pascarella 2007). These instruments captured a wide range of student experiences during university as well as a variety of student development outcomes. The information captured during this wave of the data collection process included posttest measures of the pretests administered during the initial data collection step. A total of 2,212 students participated in the follow-up data collection stage (this constitutes a $52.8 \%$ response rate). Respondents completed the parallel follow-up instruments that they initially took at the beginning of their first year. Missingness on any variable ranged from less than $1 \%$ to slightly over $3 \%$. After conducting analyses to ensure the small amount of missing data on the collaborative learning variable (less than $1 \%$ ) was not significantly related to the outcome measure (Allison 2002), I used listwise deletion to handle any missing data. The final analytical sample consisted of 2,089 respondents.

Finally, it is important to acknowledge the age of the data used in this study. Although the measures from the follow-up data collection phase are roughly a decade old, the WNS data are especially useful in answering this study's questions. Considering many studies on this topic focus on only certain majors within single institutions, this data set is especially rich in that it includes information from multiple institutions, thus enhancing the generalizability of the findings. Also important, this study tracks the same students over four years, and it also considers a wide range of potential confounders_-including a pretest measure of academic motivation. Related, given the substantial amount of higher education studies that rely on cross-sectional research designs, it is important for researchers to use longitudinal designs (like the WNS) to study higher education outcomes, as scholars have demonstrated their usefulness in controlling for potential selection effects - an especially persistent issue in studies estimating the impact of higher education on student outcomes (Astin and Lee 2003; Seifert et al. 2010).

\section{Variables}

Dependent variable

Table 1 includes the detailed definitions and descriptive statistics for all variables. The dependent variable in this study is end of fourth-year academic motivation. I captured this outcome with an eight-item standardized scale (alpha $=.74)$ that assesses respondents' overall levels of academic motivation. This particular variable is the same measure used in other research on academic motivation among university students (e.g., An 2015; Trolian and Jach 2020; Wu 2019). Some items include the degree to which the respondent believed they read more than they needed to for their classes, and the extent to which they believe that getting good grades is important, for example.

\section{Independent variable}

The independent variable in this study is collaborative learning. I measured this construct with a four-item standardized scale (alpha $=.70)$. This scale, which other researchers use in studies on collaborative learning (Castle 2014; Liu, Hu, and Pascarella 2019; Loes and Pascarella 2017) assesses the degree to which respondents relied on learning collaboratively during their time at university. Some items include the degree to which the respondent participated in study groups outside of class and the extent to which respondents taught one another in class.

\section{Control variables}

All analyses in this study include a battery of control measures. Control variables include precollege academic motivation, ACT/ACT equivalent score (hereinafter ACT), race, and sex. Given 
that only $21 \%$ of the analytical sample consist of racial and ethnic minorities, the individual racial and ethnic categories were too small for meaningful statistical analysis. Therefore, I dichotomized race into racial and ethnic minority students versus White students. Additional measures include institutional type, academic major, whether the student worked for pay while at university, on-campus residence, university grades, and participation in cocurricular activities.

Table 1. Variable definitions and descriptive statistics ${ }^{1}$

\begin{tabular}{|c|c|c|c|c|c|}
\hline Variables & Description & Mean & S.D. & Min & Max \\
\hline \multicolumn{6}{|l|}{ Dependent variable } \\
\hline $\begin{array}{l}\text { Fourth-year academic } \\
\text { motivation (alpha }= \\
0.74)\end{array}$ & $\begin{array}{l}\text { Eight-item standardized scale. Extent to } \\
\text { respondents agree or disagree with the } \\
\text { following statements: (a) I am willing to } \\
\text { work hard in a course to learn the material } \\
\text { even if it won't lead to a higher grade; (b) } \\
\text { When I do well on a test, it is usually } \\
\text { because I am well-prepared, not because } \\
\text { the test is easy; (c) I frequently do more } \\
\text { reading in a class than is required simply } \\
\text { because it interests me; (d) I frequently talk } \\
\text { to faculty outside of class about ideas } \\
\text { presented during class; (e) Getting the best } \\
\text { grades I can is very important to me; (f) I } \\
\text { enjoy the challenge of learning complicated } \\
\text { new material; (g) My academic experiences } \\
\text { (i.e., courses, labs, studying, discussions } \\
\text { with faculty) will be the most important } \\
\text { part of college; (h) My academic } \\
\text { experiences (i.e., courses, labs, studying, } \\
\text { discussions with faculty) will be the most } \\
\text { enjoyable part of college. }\end{array}$ & 0.00 & 1.00 & -3.91 & 2.58 \\
\hline \multicolumn{6}{|l|}{ Independent variable } \\
\hline $\begin{array}{l}\text { Collaborative Learning } \\
(\text { alpha }=0.70)\end{array}$ & $\begin{array}{l}\text { Four-item standardized scale. Students } \\
\text { responded to how frequently they } \\
\text { experienced the following: (1) In my } \\
\text { classes, students taught each other in } \\
\text { addition to faculty teaching; (2) faculty } \\
\text { encouraged me to participate in study } \\
\text { groups outside of class; (3) I have } \\
\text { participated in one or more study group(s) } \\
\text { outside of class; and (4) I have worked with } \\
\text { other students on projects outside class. }\end{array}$ & 0.00 & 1.00 & -1.97 & 1.52 \\
\hline \multicolumn{6}{|l|}{ Control variables } \\
\hline $\begin{array}{l}\text { Precollege academic } \\
\text { motivation (alpha = } \\
0.69)\end{array}$ & $\begin{array}{l}\text { (See dependent variable definition for list } \\
\text { of parallel scale items) }\end{array}$ & 0.00 & 1.00 & -3.43 & 2.56 \\
\hline
\end{tabular}




\begin{tabular}{|c|c|c|c|c|c|}
\hline Male & $\begin{array}{l}\text { Male student (the reference group is } \\
\text { females) }\end{array}$ & 0.36 & 0.48 & 0.00 & 1.00 \\
\hline Racial/ethnic minority & $\begin{array}{l}\text { Racial/ethnic minority student (the } \\
\text { reference group is Whites) }\end{array}$ & 0.21 & 0.40 & 0.00 & 1.00 \\
\hline ACT score & $\begin{array}{l}\text { A student's ACT score, SAT equivalent, or } \\
\text { COMPASS equivalent score for } \\
\text { community college students. Each } \\
\text { participating institution provided the score. }\end{array}$ & 27.23 & 4.27 & 14.00 & 36.00 \\
\hline $\begin{array}{l}\text { Major: } \\
\text { Natural sciences }\end{array}$ & $\begin{array}{l}\text { Student majored in a natural science } \\
\text { discipline (the reference group is non- } \\
\text { natural science majors) }\end{array}$ & 0.18 & 0.39 & 0.00 & 1.00 \\
\hline $\begin{array}{l}\text { Major: } \\
\text { Arts/humanities }\end{array}$ & $\begin{array}{l}\text { Student majored in an arts/humanities } \\
\text { discipline (the reference group is non- } \\
\text { arts/humanities majors) }\end{array}$ & 0.20 & 0.40 & 0.00 & 1.00 \\
\hline Regional university & $\begin{array}{l}\text { Respondent attends a regional university } \\
\text { (the reference group is liberal arts college) }\end{array}$ & 0.16 & 0.36 & 0.00 & 1.00 \\
\hline Research university & $\begin{array}{l}\text { Respondent attends a research university } \\
\text { (the reference group is liberal arts college) }\end{array}$ & 0.29 & 0.45 & 0.00 & 1.00 \\
\hline Worked for Pay & $\begin{array}{l}\text { Worked for pay while in college (the } \\
\text { reference group did not work) }\end{array}$ & 0.78 & 0.41 & 0.00 & 1.00 \\
\hline On-campus residence & $\begin{array}{l}\text { Respondent lives on-campus (the reference } \\
\text { group is off-campus residence) }\end{array}$ & 0.42 & 0.49 & 0.00 & 1.00 \\
\hline Co-curricular activities & $\begin{array}{l}\text { Respondent participated in co-curricular } \\
\text { activities (the reference group did not } \\
\text { participate in co-curricular activities) }\end{array}$ & 0.82 & 0.39 & 0.00 & 1.00 \\
\hline GPA & $\begin{array}{l}\text { Respondent fourth-year grades were "A-" or } \\
\text { above (the reference group is those with } \\
\text { grades of } \mathrm{B}+\text { or lower) }\end{array}$ & 0.54 & 0.50 & 0.00 & 1.00 \\
\hline
\end{tabular}

\section{Data analysis}

Data analyses were conducted in two phases using ordinary least squares regression. This statistical approach allows the researcher to estimate the influence of a specific independent variable (in this study, collaborative learning) on a dependent variable (end of fourth-year academic motivation), while also accounting for other factors that may influence the dependent variable (i.e., the control variables noted earlier). In the first phase, I estimated the main effects of collaborative learning on academic motivation by regressing end of first-year academic motivation on the collaborative learning measure as well as all the control measures noted earlier. In the second phase of the analyses, I attempted to determine whether the relationship between collaborative learning and academic motivation differs by students' racial/ethnic backgrounds. To accomplish this, I simply added the cross-product term of race $\mathrm{x}$ collaborative learning to the main effects equation.

It is important to emphasize that the longitudinal design of this study is a powerful way to adjust for selection bias (Astin and Lee 2003; Seifert et al. 2010). This approach allows one to estimate actual gains in academic motivation as a result of engaging in collaborative learning (Pascarella, Wolniak, and Pierson 2003). Next, because students within the same institutions are more alike than students among different institutions, I generated robust standard errors for all estimates to adjust for this issue (Groves 
et al. 2009). I used a variance inflation test to determine whether multicollinearity (i.e., when predictor variables are highly correlated with one another) might be biasing the estimates. The variance inflation factor, which was well within acceptable parameters, ranged from 1.04 to 1.53 , with a mean of 1.18 (Cohen et al. 2003). Lastly, I used an alpha level of 0.05 for all tests of statistical significance.

Table 2. Estimated effects of collaborative learning on end-of-fourth-year academic motivation²

\begin{tabular}{|c|c|c|}
\hline Predictor & $\begin{array}{c}\text { Model } 1 \\
\text { Coefficient } \\
\text { (Robust Standard Error) }\end{array}$ & $\begin{array}{c}\text { Model } 2 \\
\text { Coefficient } \\
\text { (Robust Standard Error) }\end{array}$ \\
\hline Precollege academic motiv. & $\begin{array}{c}0.33^{* * *} \\
(0.02)\end{array}$ & $\begin{array}{c}0.33^{* * *} \\
(0.02)\end{array}$ \\
\hline Male & $\begin{array}{c}-0.07 \\
(0.05)\end{array}$ & $\begin{array}{c}-0.07 \\
(0.05)\end{array}$ \\
\hline Racial/ethnic minority & $\begin{array}{c}0.07 \\
(0.05)\end{array}$ & $\begin{array}{c}0.07 \\
(0.05)\end{array}$ \\
\hline ACT score & $\begin{array}{c}-0.01 \\
0.01\end{array}$ & $\begin{array}{c}-0.01 \\
(0.01)\end{array}$ \\
\hline Major: Natural sciences & $\begin{array}{l}0.21^{* *} \\
(0.06)\end{array}$ & $\begin{array}{l}0.21^{* *} \\
(0.06)\end{array}$ \\
\hline Major: Arts/humanities & $\begin{array}{c}0.15^{*} \\
(0.06)\end{array}$ & $\begin{array}{c}0.15^{*} \\
(0.06)\end{array}$ \\
\hline Regional university & $\begin{array}{c}-0.07 \\
(0.06)\end{array}$ & $\begin{array}{c}-0.07 \\
(0.06)\end{array}$ \\
\hline Research university & $\begin{array}{c}-0.31^{* *} \\
(0.08)\end{array}$ & $\begin{array}{c}-0.31^{* *} \\
(0.08)\end{array}$ \\
\hline Work for pay & $\begin{array}{c}-0.05 \\
(0.06)\end{array}$ & $\begin{array}{c}-0.05 \\
(0.06)\end{array}$ \\
\hline On-campus residence & $\begin{array}{c}0.00 \\
(0.05)\end{array}$ & $\begin{array}{c}0.00 \\
(0.05)\end{array}$ \\
\hline Co-curricular activities & $\begin{array}{c}-0.07 \\
(0.04)\end{array}$ & $\begin{array}{c}-0.07 \\
(0.04)\end{array}$ \\
\hline GPA & $\begin{array}{c}0.40^{* * *} \\
(0.06)\end{array}$ & $\begin{array}{c}0.40^{* * *} \\
(0.06)\end{array}$ \\
\hline Collaborative learning & $\begin{array}{c}0.34^{* * *} \\
(0.03)\end{array}$ & $\begin{array}{c}0.34^{* * *} \\
(0.04)\end{array}$ \\
\hline Collaborative learning $\mathrm{x}$ race & & $\begin{array}{c}0.02 \\
(0.09)\end{array}$ \\
\hline Constant & $\begin{array}{c}0.17 \\
(0.20)\end{array}$ & $\begin{array}{c}0.17 \\
(0.20)\end{array}$ \\
\hline $\mathrm{R}^{2}$ & $0.28^{* * *}$ & $0.28^{* * *}$ \\
\hline
\end{tabular}




\section{RESULTS}

The first hypothesis in this study posited that collaborative learning would exert a statistically significant, net positive influence on end-of-fourth year academic motivation. Model 1 in table 2 illustrates the results from the main effects analysis. First, the overall regression model explained roughly $28 \%$ of the variance in end-of-fourth-year academic motivation. Next, and quite unsurprisingly, the results from the regression analysis reveal that precollege academic motivation exerted a strong influence on the outcome measure $(\beta=0.33, \mathrm{p}<0.001)$. With respect to the first hypothesis, exposure to collaborative learning, net of controls, is positively associated with statistically significant gains in academic motivation at the end of the fourth year of university $(\beta=0.34, p<0.001)$, suggesting that a one-standard deviation increase in collaborative learning is associated with a .34 standard deviation increase, on average, in academic motivation over four years of university. Put simply, compared to their counterparts who do not learn collaboratively, students who learn collaboratively report substantially greater gains in academic motivation as a result of engaging in this effective educational activity.

The second hypothesis in this study suggested that the influence of collaborative learning on academic motivation would vary by race. More specifically, I predicted that compared to White students, racial and ethnic minority students who learned collaboratively would exhibit greater gains in academic motivation. The collaborative learning $\mathrm{x}$ race interaction term was not statistically significant, however $(\beta=0.02, p=0.85)$. In summary, collaborative learning positively influences students' academic motivation, irrespective of their racial/ethnic background (see model 2 in table 2 ). As such, the results do not support the second hypothesis of this study.

\section{DISCUSSION}

In this study, I examined data from 17 institutions of varying size and selectivity throughout the U.S. to determine whether collaborative learning activities influence end-of-first-year academic motivation. In doing so, I also simultaneously adjusted for the potential confounding influences of one's sex, race, ACT standardized test score, institutional type, major in a natural science or arts/humanities discipline, grades, whether the respondent worked for pay while in university, participated in cocurricular activities, resided on campus, as well as their precollege academic motivation levels. In short, the findings suggest collaborative learning has a strong net positive influence on gains in academic motivation. This effect persisted over four years of university, regardless of one's racial or ethnic background.

Although some researchers may suggest using a difference score as a dependent variable, scholars have empirically demonstrated that the inclusion of a parallel pretest measure will yield the same estimates. Thus, "one does not have to use change or gain scores to either statistically or conceptually explain growth in college" (Pascarella, Wolniak, and Pierson 2003, 125). Related, the pretest measure used in this study accounted for a substantial amount of the explained variance in the outcome measure, thereby underscoring the importance of including a baseline measure of the outcome in my equations. Despite the powerful influence of the pretest measure, and the inclusion of a wide battery of other potential cofounders, the primary independent variable — collaborative learningexerted a substantial and positive influence on students' academic motivation. This effect persisted over four years of university, further underscoring the relative import of this specific pedagogical approach.

As noted earlier, academic motivation tends to decline during a student's time at university. This point, coupled with the positive outcomes associated with increased motivation, highlights the 
importance of incorporating interventions that might enhance students' motivation. Basing their rationale in self-determination theory (Deci and Ryan 1985), Brouse et al. (2010) hypothesize this drop in motivation may be the result of students' perceptions of a lack of autonomy in their own learning. In contrast to traditional forms of instruction such as lecturing, more active pedagogical approaches, such as collaborative learning, encourage students to take a more active role in their own learning (Barkley, Cross, and Major 2014; McKeachie, Svinicki, and Hofer 2006). As such, increasing opportunities for students to learn collaboratively may yield benefits in terms of enhanced academic motivation. As expected, respondents' academic motivation levels decreased slightly from the beginning of the first year of university in this study $(M=3.61, S D=.01)$ to the end of the fourth year $(M=3.41, S D=.01)$, $t(4,378)=11.37, \mathrm{p}<.001$. Despite this decline, however, student engagement in collaborative learning was associated with actual gains in academic motivation (Pascarella, Wolniak, and Pierson 2003), further reinforcing the priority that educators should place on incorporating collaborative learning into the university classroom.

An encouraging finding in the current investigation is that collaborative learning activities affect all students similarly, regardless of race or ethnicity. However, the relatively small proportion of racial and ethnic minorities in the sample (approximately 21\%), prevented a more fine-grained analysis of specific subgroups within this category. This is a noteworthy point, given the evidence suggesting differences in academic motivation levels of Black (versus White) students, for example (Roksa and Whitley 2017). As such, future research should disaggregate specific racial and ethnic groups to determine whether exposure to collaborative learning activities has differential effects on the academic motivation of these students. Despite the results of prior research (Barkley, Cross, and Major 2014; Fullilove and Treisman 1990; Slavin and Oickle 1981a; Springer, Stanne, and Donovan 1999) suggesting that compared to their White counterparts, racial and ethnic minority students generally benefit more from collaborative learning, the results from this study suggest the benefits in terms of academic motivation are not dependent on one's race or ethnicity.

The absence of moderating effects by race in this study is somewhat curious. In their investigation of middle-school students, Slavin and Oickle (1981) found racial and ethnic minority students benefitted more in terms of test scores compared to their White counterparts as a result of learning collaboratively. They argue the treatment $\mathrm{x}$ race effect may be due to a possible treatment $\mathrm{x}$ pretest interaction (with low-performing students — regardless of race or ethnicity-gaining more in the outcome measure from the treatment when compared to high-performing students). Many of the issues identified in previous research on collaborative learning and academic motivation are ameliorated in the current study with the inclusion of controls for precollege academic ability amongst all respondents as well as the parallel pretest of the outcome measure.

Despite some single-institution work suggesting a positive link between active and collaborative learning activities and enhanced academic motivation generally (e.g., Benware and Deci 1984), and among engineering students, specifically (Jones et al. 2013), there is little contemporary research that explores this issue-especially following students from multiple institutions throughout four years of university. The results of this study suggest that collaborative learning is positively associated with gains in academic motivation, which underscores the theoretical arguments of Vygotsky (1978) that student development is best understood within one's social context. More specifically, motivation increases as a result of the opportunities for group members to take more agency in their own learning. This motivation, then, can best be understood as an outcome that manifests itself through a socially 
negotiated process that is naturally enhanced by the situational aspects of learning (Ambrose et al. 2010; Eyler 2018; Sivan 1986). Additionally, results of the interaction effects analysis reveal that the collaborative learning positively influences academic motivation, regardless of one's racial or ethnic background.

Although this study expands what we know about the relationship between collaborative learning and academic motivation, there are some important limitations worth noting. First, the variables used in this study allow one to identify whether a student has learned collaboratively; however, it is impossible to discern what, exactly, occurs in those collaborative learning groups. Next, this study examined only 17 higher education institutions. As such, one cannot necessarily generalize the findings presented to all universities in the U.S. That noted, one particular strength of the institutional sample is the inclusion of schools from varying sizes, selectivity, and type throughout the nation. Further, the longitudinal design, especially throughout all four years of university, make this data set especially unique in its potential to test the hypotheses presented.

\section{Study implications}

The findings from this investigation have several important implications for university students and instructors. First, there are a range of important student learning outcomes associated with enhanced academic motivation. Scholars link academic motivation to greater odds of persistence to the second and third years of university (Allen 1999; Lotkowski, Robbins, and Noeth 2004), university grades (Lotkowski, Robbins, and Noeth 2004), greater ability to manage stress and adversity (Reynolds and Weigand 2010), and psychological well-being (Burton et al. 2006), for example. Considering the wealth of student outcomes associated with university students' academic motivation, and bearing in mind scholars' recommendations to examine academic motivation as an outcome in higher education research (e.g., Guiffrida 2006), researchers should continue to use longitudinal research designs in investigating how effective pedagogical approaches such as collaborative learning might influence this important student outcome. Higher education institutions wishing to enhance student success in the areas noted above may consider focusing on students' academic motivation levels. Likewise, if universities do indeed desire to increase students' academic motivation, the results of this research suggest that institutions might achieve this outcome by focusing on incorporating more collaborative learning activities into the teaching and learning process.

Instructors who endeavor to incorporate more collaborative learning activities into their instructional repertoire might consider specific activities such as "think-pair-share," whereby instructors ask students to briefly turn to one another after important concepts are presented in class to share and compare their comprehension of the material. Similarly, instructors may consider using "learning cells" whereby students partner with one another to exchange quizzes they design over the day's required readings. University faculty who desire to strengthen their own collaborative learning activities can also consult a number of resources written on this topic (e.g., Barkley, Cross, and Major 2014; Kyndt et al. 2013).

Collaborative learning is associated with an impressive number of important student outcomes including critical thinking (Loes and Pascarella 2017), academic achievement (Springer, Stanne, and Donovan 1999), and persistence to the second year of university (Loes et al. 2017; Tinto 1999). Considering the established links between collaborative learning and these outcomes, as well as the positive association with academic motivation uncovered in this study, instructors and institutions 
wishing to enhance students' chances of achieving these outcomes should consider incorporating collaborative learning into the pedagogical repertoire of instructors. Doing so has the potential to benefit students and institutions alike.

\section{ACKNOWLEDGEMENTS}

This research is based on a grant from the Center of Inquiry in the Liberal Arts at Wabash College to the Center for Research on Undergraduate Education at The University of Iowa.

Chad N. Loes is Professor and Chair in the Department of History, Politics, and Justice at Mount Mercy University (Cedar Rapids, IA, USA).

\section{NOTES}

1. Sample size is 2,089 respondents.

2. The academic motivation and collaborative learning scales are standardized. Sample size is 2,089 . Estimates are adjusted for clustering. ${ }^{*} p<0.05,{ }^{* *} p<0.01,{ }^{* * *} p<0.001$.

\section{REFERENCES}

Allen, David. 1999. "Desire to Finish College: An Empirical Link between Motivation and Persistence." Research in Higher Education 40 (4): 461-85. https://doi.org/10.1023/A:1018740226006.

Allison, Paul D. 2002. Missing Data. Thousand Oaks, CA: SAGE Publications.

Ambrose, Susan A., Michael W. Bridges, Michele DiPietro, Marsha C. Lovett, and Marie K. Norman. 2010. How Learning Works: Seven Research-Based Principles for Smart Teaching. John Wiley \& Sons.

Ames, Carole, and Russell Ames. 1984. "Systems of Student and Teacher Motivation: Toward a Qualitative Definition." Journal of Educational Psychology 76 (4): 535-56. https://doi.org/10.1037/0022-0663.76.4.535.

An, Brian P. 2015. "The Role of Academic Motivation and Engagement on the Relationship between Dual Enrollment and Academic Performance." The Journal of Higher Education 86 (1): 98-126. https://doi.org/10.1080/00221546.2015.11777358.

Astin, Alexander. 1993. What Matters in College? Four Critical Years Revisited. San Francisco, CA: Jossey-Bass.

Astin, Alexander, and Jenny Lee. 2003. "How Risky Are One-Shot Cross-Sectional Assessments of Undergraduate Students?" Research in Higher Education 44 (6): 657-72. https://doi.org/10.1023/A:1026175525173.

Baker, Vicki L., Roger G. Baldwin, and Sumedha Makker. 2012. "Where Are They Now? Revisiting Breneman's Study of Liberal Arts Colleges." Liberal Education 98 (3): 48-53.

Barkley, Elizabeth, K. Patricia Cross, and Claire Major. 2014. Collaborative Learning Techniques: A Handbook for College Faculty. San Francisco, CA: Jossey-Bass.

Benware, Carl A., and Edward L. Deci. 1984. "Quality of Learning with an Active versus Passive Motivational Set." American Educational Research Journal 21 (4): 755-65. https://doi.org/10.3102/00028312021004755.

Blaich, Charles F., and K. Wise. 2011. "From Gathering to Using Assessment Results: Lessons from the Wabash National Study (NILOA Occasional Paper No. 8)." In. Urbana, IL: University of Illinois and Indiana University, National Institute for Learning Outcomes Assessment.

Brophy, Jere E. 2004. Motivating Students to Learn. 2nd ed. Mahwah, NJ: Routledge.

Brouse, Corey H., Charles E. Basch, Michael LeBlanc, Kelly R. McKnight, and Ting Lei. 2010. "College Students' Academic Motivation: Differences by Gender, Class, and Source of Payment." College Quarterly 13 (1). https://eric.ed.gov/?id=EJ912093.

Burton, Kimberly D., John E. Lydon, David U. D’Alessandro, and Richard Koestner. 2006. "The Differential Effects of Intrinsic and Identified Motivation on Well-Being and Performance: Prospective, Experimental, and Implicit Approaches to Self-Determination Theory." Journal of Personality and Social Psychology 91 (4): 750 62. https://doi.org/10.1037/0022-3514.91.4.750.

"Carnegie Classifications: Undergraduate Instructional Program Classification." n.d. Accessed August 6, 2021. https://carnegieclassifications.iu.edu/classification_descriptions/ugrad_program.php. 
Castle, Thomas D. 2014. "The Impact of Cooperative Learning on the Development of Need for Cognition among First-Year College Students." The University of lowa. http://ir. uiowa.edu/etd/1437.

Cicuto, Camila Aparecida Tolentino, and Bayardo Baptista Torres. 2016. "Implementing an Active Learning Environment to Influence Students' Motivation in Biochemistry." Journal of Chemical Education 93 (6): 1020 26. https://doi.org/10.1021/acs.jchemed.5b00965.

Cohen, Jacob, Patricia Cohen, Stephen G. West, and Leona S. Aiken. 2003. Applied Multiple Regression/Correlation Analysis for the Behavioral Sciences. 3rd ed. Mahwah, NJ: L. Erlbaum Associates.

Crone, lan, and Kathy MacKay. 2007. "Motivating Today's College Students." Peer Review 9 (1): 18-21.

Deci, Edward L., and Richard M. Ryan. 1985. "Conceptualizations of Intrinsic Motivation and Self-Determination." In Intrinsic Motivation and Self-Determination in Human Behavior, edited by Edward L. Deci and Richard M. Ryan, 11-40. Perspectives in Social Psychology. Boston, MA: Springer US. https://doi.org/10.1007/978-14899-2271-7 2.

Deci, Edward L., and Richard M. Ryan. 2012. "Motivation, Personality, and Development within Embedded Social Contexts: An Overview of Self-Determination Theory." In The Oxford Handbook of Human Motivation, 85-107. Oxford Library of Psychology. New York, NY, US: Oxford University Press.

Eccles, Jacquelynne S., and Allan Wigfield. 2002. "Motivational Beliefs, Values, and Goals." Annual Review of Psychology 53 (1): 109-32. https://doi.org/10.1146/annurev.psych.53.100901.135153.

El'konin, Daniil. 1972. "Toward the Problem of Stages in the Mental Development of the Child." Soviet Psychology 10 (3): 225-51. https://doi.org/10.2753/RPO1061-04051003225.

Eyler, Joshua R. 2018. How Humans Learn: The Science and Stories behind Effective College Teaching. Morgantown: West Virginia University Press. https://muse.jhu.edu/book/62882.

Freeman, Scott, Sarah L. Eddy, Miles McDonough, Michelle K. Smith, Nadozie Okoroafor, Hannah Jordt, and Mary Pat Wenderoth. 2014. "Active Learning Increases Student Performance in Science, Engineering, and Mathematics." Proceedings of the National Academy of Sciences 111 (23): 8410-15. https://doi.org/10.1073/pnas.1319030111.

Fullilove, Robert E., and Philip Uri Treisman. 1990. "Mathematics Achievement Among African American Undergraduates at the University of California, Berkeley: An Evaluation of the Mathematics Workshop Program." The Journal of Negro Education 59 (3): 463-78. https://doi.org/10.2307/2295577.

Goodenow, Carol, and Kathleen E. Grady. 1993. “The Relationship of School Belonging and Friends' Values to Academic Motivation among Urban Adolescent Students." The Journal of Experimental Education 62 (1): 60 71. https://doi.org/10.1080/00220973.1993.9943831.

Grouzet, Frederick M. E., Nancy Otis, and Luc G. Pelletier. 2006. "Longitudinal Cross-Gender Factorial Invariance of the Academic Motivation Scale." Structural Equation Modeling: A Multidisciplinary Journal 13 (1): 73-98. https://doi.org/10.1207/s15328007sem1301_4.

Groves, Robert M., Floyd J. Fowler, Mick P. Couper, James M. Lepkowsi, Eleanor Singer, and Roger Tourangeau. 2009. Survey Methodology. 2nd ed. Hoboken, NJ: Wiley-Interscience.

Guiffrida, Douglas A. 2006. "Toward a Cultural Advancement of Tinto's Theory." The Review of Higher Education 29 (4): 451-72. https://doi.org/10.1353/rhe.2006.0031.

Hulleman, Chris S., Kenneth E. Barron, Jeff J. Kosovich, and Rory A. Lazowski. 2016. "Student Motivation: Current Theories, Constructs, and Interventions within an Expectancy-Value Framework." In Psychosocial Skills and School Systems in the 21st Century: Theory, Research, and Practice, edited by Anastasiya A. Lipnevich, Franzis Preckel, and Richard D. Roberts, 241-78. The Springer Series on Human Exceptionality. Cham: Springer International Publishing. https://doi.org/10.1007/978-3-319-28606-8 10.

Järvelä, Sanna, Simone Volet, and Hanna Järvenoja. 2010. "Research on Motivation in Collaborative Learning: Moving beyond the Cognitive-Situative Divide and Combining Individual and Social Processes." Educational Psychologist 45 (1): 15-27. https://doi.org/10.1080/00461520903433539.

Johnson, David W., Roger T. Johnson, and Karl Smith. 2007. "The State of Cooperative Learning in Postsecondary and Professional Settings." Educational Psychology Review 19 (1): 15-29. https://doi.org/10.1007/s10648-0069038-8.

Johnson, David W., Roger T. Johnson, and Karl A. Smith. 1991. Active Learning: Cooperation in the College Classroom. Edina, MN: Interaction Book Co. 
Jones, Brett, Cory Epler, Parastou Mokri, Lauren Bryant, and Marie Paretti. 2013. "The Effects of a Collaborative Problem-Based Learning Experience on Students' Motivation in Engineering Capstone Courses." Interdisciplinary Journal of Problem-Based Learning 7 (2). https://doi.org/10.7771/1541-5015.1344.

Komarraju, Meera, Sergey Musulkin, and Gargi Bhattacharya. 2010. "Role of Student-Faculty Interactions in Developing College Students' Academic Self-Concept, Motivation, and Achievement." Journal of College Student Development 51 (3): 332-42. https://doi.org/10.1353/csd.0.0137.

Kowalski, Patricia. 2007. "Changes in Students' Motivation to Learn during the First Year of College." Psychological Reports 101 (1): 79-89. https://doi.org/10.2466/pr0.101.1.79-89.

Kyndt, Eva, Elisabeth Raes, Bart Lismont, Fran Timmers, Eduardo Cascallar, and Filip Dochy. 2013. "A MetaAnalysis of the Effects of Face-to-Face Cooperative Learning. Do Recent Studies Falsify or Verify Earlier Findings?" Educational Research Review 10 (December): 133-49. https://doi.org/10.1016/j.edurev.2013.02.002.

Laal, Marjan, Loabat Geranpaye, and Mahrokh Dunkin. 2013. "Individual Accountability in Collaborative Learning" 93: 286-89.

Laal, Marjan, and Seyed M. Ghodsi. 2012. "Benefits of Collaborative Learning." 31: 486-90.

Legault, Lisa, Isabelle Green-Demers, and Luc Pelletier. 2006. "Why Do High School Students Lack Motivation in the Classroom? Toward an Understanding of Academic Amotivation and the Role of Social Support." Journal of Educational Psychology 98 (3): 567-82. https://doi.org/10.1037/0022-0663.98.3.567.

Liu, Jiajun, Shouping Hu, and Ernest T. Pascarella. 2019. “Are Non-Native English Speaking Students Disadvantaged in College Experiences and Cognitive Outcomes?" Journal of Diversity in Higher Education, Advance online publication. https://doi.org/10.1037/dhe0000164.

Loes, Chad N., Brian P. An, Kem Saichaie, and Ernest T. Pascarella. 2017. "Does Collaborative Learning Influence Persistence to the Second Year of College?" The Journal of Higher Education 88 (1): 62-84. https://doi.org/10.1080/00221546.2016.1243942.

Loes, Chad N., K. C. Culver, and Teniell L. Trolian. 2018. "How Collaborative Learning Enhances Students' Openness to Diversity." The Journal of Higher Education 89 (6): 935-60. https://doi.org/10.1080/00221546.2018.1442638.

Loes, Chad N., and Ernest T. Pascarella. 2017. "Collaborative Learning and Critical Thinking: Testing the Link." The Journal of Higher Education 88 (5): 726-53. https://doi.org/10.1080/00221546.2017.1291257.

Lotkowski, Veronica A., Steven B. Robbins, and Richard J. Noeth. 2004. The Role of Academic and Non-Academic Factors in Improving College Retention. ACT Policy Report. American College Testing ACT Inc. https://eric.ed.gov/?id=ed485476.

McKeachie, Wilbert J., Marilla Svinicki, and Barbara Hofer. 2006. Mckeachie's Teaching Tips: Strategies, Research, and Theory for College and University Teachers. Boston, MA: Houghton Mifflin Harcourt.

Panitz, Theodore. 1999. "The Motivational Benefits of Cooperative Learning." New Directions for Teaching and Learning.

Pascarella, Ernest T. 2007. "Methodological Report for Wabash National Study of Liberal Arts Education." 2007. https://centerofinquiry.org/wp-content/uploads/2017/04/WNSLAE_Research_Methods_March_2008.pdf.

Pascarella, Ernest T., Gregory C. Wolniak, and Christopher T. Pierson. 2003. "Explaining Student Growth in College When You Don't Think You Are." Journal of College Student Development 44 (1): 122-26. https://doi.org/10.1353/csd.2003.0007.

Piaget, Jean. 1926. The Language and Thought of a Child. New York, NY: Harcourt, Brace.

Piaget, Jean. 1950. The Psychology of Intelligence. New York, NY: Harcourt.

Ratelle, Catherine F., Frédéric Guay, Simon Larose, and Caroline Senécal. 2004. "Family Correlates of Trajectories of Academic Motivation during a School Transition: A Semiparametric Group-Based Approach." Journal of Educational Psychology 96 (4): 743-54. https://doi.org/10.1037/0022-0663.96.4.743.

Raver, Sharon A., and Ann S. Maydosz. 2010. "Impact of the Provision and Timing of Instructor-Provided Notes on University Students' Learning." Active Learning in Higher Education 11 (3): 189-200. https://doi.org/10.1177/1469787410379682.

Reynolds, Amy L., and Matthew J. Weigand. 2010. "The Relationships among Academic Attitudes, Psychological Attitudes, and the First-Semester Academic Achievement of First-Year College Students." Journal of Student Affairs Research and Practice 47 (2): 175-95. https://doi.org/10.2202/1949-6605.6004. 
Roksa, Josipa, and Sarah E. Whitley. 2017. "Fostering Academic Success of First-Year Students: Exploring the Roles of Motivation, Race, and Faculty." Journal of College Student Development 58 (3): 333-48. https://doi.org/10.1353/csd.2017.0026.

Schunk, Dale H., and Barry J. Zimmerman. 2012. Motivation and Self-Regulated Learning: Theory, Research, and Applications. Routledge.

Seifert, Tricia A., Ernest T. Pascarella, Sherri I. Erkel, and Kathleen M. Goodman. 2010. "The Importance of Longitudinal Pretest-Posttest Designs in Estimating College Impact." New Directions for Institutional Research 2010 (December): 5-16. https://doi.org/10.1002/ir.368.

Seli, Paul, Jeffrey D. Wammes, Evan F. Risko, and Daniel Smilek. 2016. "On the Relation between Motivation and Retention in Educational Contexts: The Role of Intentional and Unintentional Mind Wandering." Psychonomic Bulletin \& Review 23 (4): 1280-87. https://doi.org/10.3758/s13423-015-0979-0.

Sivan, Eva. 1986. "Motivation in Social Constructivist Theory." Educational Psychologist 21 (3): 209-33. https://doi.org/10.1207/s15326985ep21034.

Slavin, Robert E., and Eileen Oickle. 1981. "Effects of Cooperative Learning Teams on Student Achievement and Race Relations: Treatment by Race Interactions." Sociology of Education 54 (3): 174-80. https://doi.org/10.2307/2112329.

Springer, Leonard, Mary Elizabeth Stanne, and Samuel S. Donovan. 1999. "Effects of Small-Group Learning on Undergraduates in Science, Mathematics, Engineering and Technology: A Meta-Analysis." Review of Educational Research 69 (1): 21-52. https://doi.org/10.3102/00346543069001021.

Stover, Juliana Beatriz, Guadalupe de la Iglesia, Antonio Rial Boubeta, and Mercedes Fernández Liporace. 2012. "Academic Motivation Scale: Adaptation and Psychometric Analyses for High School and College Students." Psychology Research and Behavior Management 5 (July): 71-83. https://doi.org/10.2147/PRBM.S33188.

Struthers, C. Ward, Raymond P. Perry, and Verena H. Menec. 2000. "An Examination of the Relationship among Academic Stress, Coping, Motivation, and Performance in College." Research in Higher Education 41 (5): $581-$ 92. https://doi.org/10.1023/A:1007094931292.

Stump, Glenda S., Jonathan C. Hilpert, Jenefer Husman, Wen-ting Chung, and Wonsik Kim. 2011. "Collaborative Learning in Engineering Students: Gender and Achievement." Journal of Engineering Education 100 (3): $475-$ 97. https://doi.org/10.1002/j.2168-9830.2011.tb00023.x.

"Survey Instruments." n.d. NSSE: Evidence-Based Improvement in Higher Education. Accessed August 6, 2021. https://nsse.indiana.edu//nsse/survey-instruments/index.html.

Terenzini, Patrick T., Alberto F. Cabrera, Carol L. Colbeck, John M. Parente, and Stefani A. Bjorklund. 2001. "Collaborative Learning vs. Lecture/Discussion: Students' Reported Learning Gains." Journal of Engineering Education 90 (1): 123-30. https://doi.org/10.1002/j.2168-9830.2001.tb00579.x.

Tinto, Vincent. 1997. "Classrooms as Communities: Exploring the Educational Character of Student Persistence." Journal of Higher Education 68 (6): 599-623. https://doi.org/10.2307/2959965.

Tinto, Vincent. 1998. "Colleges as Communities: Taking Research on Student Persistence Seriously." Review of Higher Education 21 (2): 167-77.

Tinto, Vincent. 1999. "Taking Retention Seriously: Rethinking the First Year of College." NACADA Journal 19 (2): 59. https://doi.org/10.12930/0271-9517-19.2.5.

Tolsgaard, Martin G., Kulamakan M. Kulasegaram, and Charlotte V. Ringsted. 2016. "Collaborative Learning of Clinical Skills in Health Professions Education: The Why, How, When and for Whom." Medical Education 50 (1): 69-78. https://doi.org/10.1111/medu.12814.

Treisman, Phillip M. 1985. "A Study of the Mathematics Performance of Black Students at the University of California, Berkeley." Unpublished doctoral dissertation, University of California, Berkeley.

Trolian, Teniell L., and Elizabeth A. Jach. 2020. "Engagement in College and University Applied Learning Experiences and Students' Academic Motivation." Journal of Experiential Education 43 (3): 317-35. https://doi.org/10.1177/1053825920925100.

Tudge, Jonathan and Barbara Rogoff. 1989. "Peer Influences on Cognitive Development: Piagetian and Vygotskian Perspectives." In In M. Bornstein \& J. Bruner (Eds.) Interaction in Human Development. Hillsdale, NJ: Lawrence Erlbaum Associates.

Twenge, Jean M., and Kristin Donnelly. 2016. "Generational Differences in American Students' Reasons for Going to College, 1971-2014: The Rise of Extrinsic Motives." Journal of Social Psychology 156 (6): 620-29.

https://doi.org/10.1080/00224545.2016.1152214. 
Vallerand, Robert J., and Robert Blssonnette. 1992. "Intrinsic, Extrinsic, and Amotivational Styles as Predictors of Behavior: A Prospective Study." Journal of Personality 60 (3): 599-620. https://doi.org/10.1111/j.14676494.1992.tb00922.x.

van der Wende, Marijk van der. 2011. "The Emergence of Liberal Arts and Sciences Education in Europe: A Comparative Perspective." Higher Education Policy 24 (2): 233-53. https://doi.org/10.1057/hep.2011.3.

Vygotsky, Lev S. 1978. Mind in Society: The Development of Higher Psychological Processes. Cambridge, MA: Harvard University Press.

Walker, Christopher O., Barbara A. Greene, and Robert A. Mansell. 2006. "Identification with Academics, Intrinsic/Extrinsic Motivation, and Self-Efficacy as Predictors of Cognitive Engagement." Learning and Individual Differences 16 (1): 1-12. https://doi.org/10.1016/j.lindif.2005.06.004.

Wentzel, Kathryn R. 1999. "Social-Motivational Processes and Interpersonal Relationships: Implications for Understanding Motivation at School." Journal of Educational Psychology 91 (1): 76-97. https://doi.org/10.1037/0022-0663.91.1.76.

Wu, Zebing. 2019. "Academic Motivation, Engagement, and Achievement among College Students." College Student Journal 53 (1): 99-112.

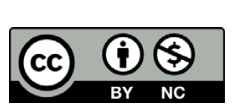

Copyright for the content of articles published in Teaching \& Learning Inquiry resides with the authors, and copyright for the publication layout resides with the journal. These copyright holders have agreed that this article should be available on open access under a Creative Commons Attribution License 4.0 International (https://creativecommons.org/licenses/by-nc/4.0/). The only constraint on reproduction and distribution, and the only role for copyright in this domain, should be to give authors control over the integrity of their work and the right to be properly acknowledged and cited, and to cite Teaching \& Learning Inquiry as the original place of publication. Readers are free to share these materials-as long as appropriate credit is given, a link to the license is provided, and any changes are indicated. 